\title{
High Latitude Corals Tolerate Severe Cold Spell
}

\author{
Chenae A. Tuckett* and Thomas Wernberg \\ School of Biological Sciences, UWA Oceans Institute, University of Western Australia, Crawley, WA, Australia
}

Climatically extreme weather events often drive long-term ecological responses of ecosystems. By disrupting the important symbiosis with zooxanthellae, Marine Cold Spells (MCS) can cause bleaching and mortality in tropical and subtropical scleractinian corals. Here we report on the effects of a severe MCS on high latitude corals, where we expected to find bleaching and mortality. The MCS took place off the coast of Perth $\left(32^{\circ}\right.$ S), Western Australia in 2016. Bleaching was assessed before (2014) and after (2017) the MCS from surveys of permanent plots, and with timed bleaching searches. Temperature data was recorded with in situ loggers. During the MCS temperatures dipped to the coldest recorded in ten years $\left(15.3^{\circ} \mathrm{C}\right)$ and periods of $<17^{\circ} \mathrm{C}$ lasted for up to 19 days. Only $4.3 \%$ of the surveyed coral colonies showed signs of bleaching. Bleaching was observed in 8 species where those most affected were Plesiastrea versipora and Montipora mollis. These findings suggest that high latitude corals in this

OPEN ACCESS

Edited by:

Emma Camp

University of Technology Sydney,

Australia

Reviewed by:

Anthony William Larkum

University of Technology Sydney,

Australia

Aldo Cróquer,

Simón Bolívar University, Venezuela

*Correspondence:

Chenae A. Tuckett

chenae.tuckett@research.uwa.edu.au

Specialty section:

This article was submitted to

Coral Reef Research,

a section of the journal

Frontiers in Marine Science

Received: 31 July 2017 Accepted: 16 January 2018

Published: 31 January 2018

Citation:

Tuckett CA and Wernberg T (2018)

High Latitude Corals Tolerate Severe

Cold Spell. Front. Mar. Sci. 5:14.

doi: 10.3389/fmars.2018.00014 area are tolerant of cold stress and are not persisting near a lethal temperature minimum. It has not been established whether other environmental conditions are limiting these species, and if so, what the implications are for coral performance on these reefs in a warmer future.

Keywords: Marine cold spell (MCS), coral bleaching, Plesiastrea versipora, Montipora mollis, stress-tolerant species

\section{INTRODUCTION}

Extreme weather events can cause long term ecological changes by impacting species across multiple scales from physiological performance to biogeographic distributions (e.g., Gaines and Denny, 1993; Hawkins et al., 2009). In the marine environment, extreme temperature events can be particularly detrimental with potentially wide ranging and catastrophic impacts (e.g., Southward and Burrows, 1995; Garrabou et al., 2009; Lirman et al., 2011; Wernberg et al., 2016). Both marine heatwaves (MHW's) and cold spells (MCS's) have only recently been defined in the literature (MHW's; Hobday et al., 2016, MCS; Schlegel et al., 2017). However, in contrast to many recent examples of impacts of MHWs, MCS's have received much less attention (Schlegel et al., 2017).

Marine Cold Spells often result from upwelling and/or atmospheric forcing (Schlegel et al., 2017) causing temperature declines, resulting in reduced metabolic capacity and stress in warm-adapted organisms (e.g., invertebrate mortality; Gunter, 1951; Firth et al., 2011, fish kills; Gunter, 1941, 1951; Holt and Holt, 1983; Rehage et al., 2016, coral bleaching; Roberts et al., 1982; Paz-García et al., 2012).

Temperature is a key factor determining the distribution of scleractinian corals, as they are generally warm water species confined to tropical and subtropical latitudes (Wells, 1957; Stehli and Wells, 1971; Veron, 1995). As seasonally cool isotherms limits the performance and distribution 
of many corals, this group of species can be expected to be sensitive to severely cooler conditions such as Marine Cold Spells (MCS). For tropical and subtropical scleractinian corals cold stress has been shown to impact the symbiotic relationship with zooxanthellae (Krause, 1992; Saxby et al., 2003; Hoegh-Guldberg et al., 2005). Under cold stress the onset of Photosystem II quenching in the zooxanthellae slows, which causes an excess of oxygen to build up in the tissue (Krause, 1992). Similar to warm water stress the excess oxygen can cause the formation of oxygen radicals, leading to tissue damage and the expulsion of the zooxanthellae (coral bleaching) (Saxby et al., 2003; HoeghGuldberg et al., 2005; Pontasch et al., 2017). Extreme cold stress, such as MCS, has thus been shown to be limiting for lower latitude corals and symbionts, and induce coral bleaching.

In addition to causing photosynthetic declines and disruptions to the coral-zooxanthellae symbiosis, cold stress can be lethal. Exposure to cold stress $\left(3-11^{\circ} \mathrm{C}\right.$ below ambient) for as little as $9-12 \mathrm{~h}$ initially induces reduced photosynthesis and coral bleaching but beyond $12 \mathrm{~h}$ at severe cold stress $\left(11^{\circ} \mathrm{C}\right.$ below ambient) coral mortality can occur (Saxby et al., 2003). Cold spells have resulted in large scale coral bleaching on low latitude reefs such as the Great Barrier Reef (Australia, $23^{\circ} \mathrm{S}$ ), where living coral cover plummeted from $>80$ to $<12 \%$ (Hoegh-Guldberg et al., 2005). Similarly in Florida (USA, $24-27^{\circ} \mathrm{N}$ ) coral mortality averaged $90 \%$ in some areas following cooler temperatures of $15^{\circ} \mathrm{C}$ (Voss, 1973; Davis, 1982; Roberts et al., 1982). MCS's thus have the potential to be significant drivers of stress and mortality in coral communities.

Modern coral communities in high latitude areas of Western Australia are typified by coral species with wide geographical ranges, or subtropical or temperate affinity (Greenstein and Pandolfi, 2008). These species are largely generalists with broad niche requirements (Sommer et al., 2014; Keith et al., 2015; Mizerek et al., 2016), and they regularly experience temperatures that are considered "cold" $\left(<18^{\circ} \mathrm{C}\right)$, for these inherently tropical taxa (Veron, 1995). Although resilient, these corals are not impervious to the stressful conditions at high latitudes. For example high latitude conditions suppress reef building processes and limit corals to distinct communities (Kleypas et al., 1999). Furthermore, these populations are locally adapted, reproductively isolated and have low genetic diversity (Ayre and Hughes, 2004; Miller and Ayre, 2008; Noreen et al., 2009; Thomas et al., 2017). Similar to what has been observed in low latitude corals, cold stress, such as can be expected during unusually cold MCS, could be limiting for corals and symbionts and induce bleaching in high latitude corals.

In this study, we documented responses of high latitude corals to a severe MCS off the coast of Perth $\left(32^{\circ} \mathrm{S}\right)$, Western Australia, where the coolest water temperatures in more than a decade, were recorded in the austral winter of 2016. As cold stress impairs metabolic processes and survival for low latitude coral reefs we expected the MCS to have caused stress in corals around Perth. As a result, we hypothesized that the high latitude coral communities would have undergone widespread bleaching and mortality from cold stress experienced during the 2016 MCS.

\section{METHODS}

This study took place in Marmion Marine Park off the coast of Perth, Western Australia (Figure 1).

In June 2014, five permanent plots of one meter diameter $\left(3.14 \mathrm{~m}^{2}\right)$, were established at three offshore sites of comparable habitat and environmental conditions. The center of each plot was marked with a labeled stake for later identification. Plots were established haphazardly across the limestone reef, separated by a minimum of 10 meters at a depth of $8-12 \mathrm{~m}$ in areas dominated by corals, turf and fleshy seaweeds. Each plot was mapped for coral colonies, and each colony was photographed with a scale (Three Mile Reef North and South), or the whole plot was photographed as visual reference (Centaur Reef). Photographs were used for subsequent measurements of size and colony health, by comparing against a coral health chart (www.coralwatch.org) to quantify levels of bleaching. For this study, only colonies with color codes B1, C1, D1, or E1 were considered to be bleached (www.coralwatch.org). This avoided potentially assigning bleaching status to colonies with perpetual lighter pigmentation or seasonal pigment variation. Plots were surveyed in September-October 2014 prior to the marine cold spell of 2016. Survey sites were visited regularly (every $\sim 2-3$ months between 2014 and 2015, monthly 2015-2016, and $\sim 3-$ 4 months 2016-2017) and bleaching in $>1$ colony was not noted. Coral bleaching was noted anecdotally in plots in December 2016, prompting a resurvey in January 2017 (austral summer). Summer temperatures prior to the surveys were comparable to regularly recorded high temperatures (December average 2006$15=21.4^{\circ} \mathrm{C}\left(\max 24.0^{\circ} \mathrm{C}\right)$ vs. December average $2016=21.7^{\circ} \mathrm{C}$ $\left(\max 24.0^{\circ} \mathrm{C}\right)$; Wernberg unpublished data) and unlikely to have been the source of bleaching. Overgrowth by turf algae on all bleached colonies further indicated that the bleaching had not occurred more recently in December 2016, immediately prior to the re-surveys. Due to loss of labeled stakes three plots were surveyed from Three Mile Reef North, four from Three Mile Reef South and four from Centaur Reef in 2017. In addition to the permanent plots, timed searches for additional coral bleaching was also undertaken in January and February 2017, at all three sites as well as at an additional three inshore sites (Figure 1). All colonies encountered in the $30 \mathrm{~min}$ searches were photographed for subsequent measurements of size and colony health (as above).

Chi-square goodness of fit tests were used to determine if the proportion of bleached colonies was significantly different between species, and between inshore and offshore reefs.

Temperature was recorded in situ every hour by an Onset Tidbit logger attached to a stake $\sim 5 \mathrm{~cm}$ above the reef surface at Centaur Reef (Figure 1). See Smale and Wernberg (2009) for additional information.

\section{RESULTS}

During 2016 temperatures in Marmion dipped to $15.3^{\circ} \mathrm{C}$, the coldest temperature recorded in $>10$ years. Anomalously cold temperatures occurred in nine months of the year, based on ten year average monthly temperatures, and a continuous period of 
$<17^{\circ} \mathrm{C}$ (below any long term monthly average) occurred for $\sim 19$ days during August-September (Figure 2). In the months prior to bleaching being noted in December 2016, other temperature anomalies (e.g., heat spikes) were not seen (Figure 2).

A total of 244 coral colonies were found and re-surveyed in the nine permanent plots after the marine cold spell (Figure 3) and the number of colonies increased in total due to an increased number of small corals $(<1 \mathrm{~cm})$ (Table 1). The number of bleached colonies increased from zero before to ten $(4.3 \%)$ after the MCS, and of the ten bleached corals four were $>50 \%$ bleached and six $<50 \%$ bleached (Figure 4A). The bleached colonies occurred at all sites and were found in six of the nine plots. Bleaching was found in two of the ten species recorded within the plots. Montipora mollis had slightly

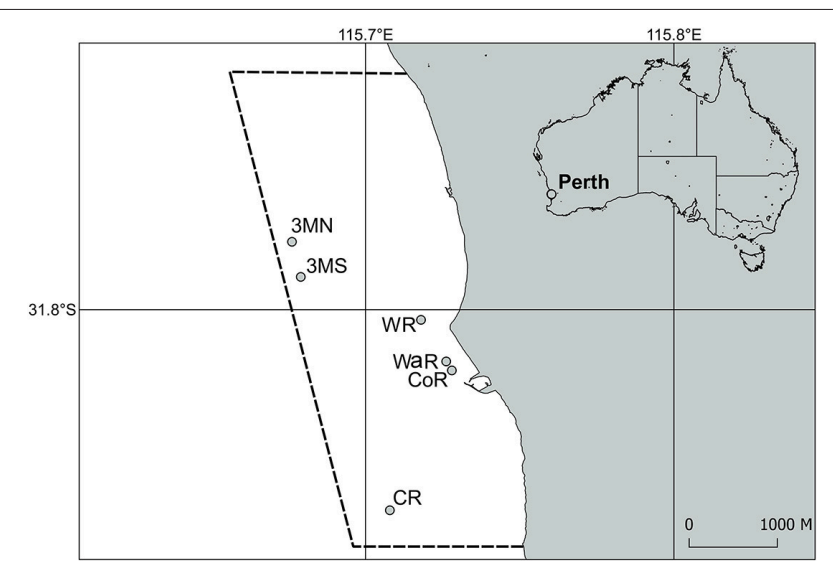

FIGURE 1 | Sample region and sites within Marmion Marine Park off of Perth, Western Australia. The dashed lines indicate the boundary of the marine park. 3MN, Three Mile Reef North; 3MS, Three Mile Reef South; WR, Wreck Rock; WaR, Wanneroo Reef; CoR, Cow Rocks; CR, Centaur Reef. more bleached colonies than Plesiastrea versipora (Figure 4B). Of the 234 healthy colonies the majority were $P$. versipora and Paragoniastrea australensis (Figure 4C). A large majority of the healthy colonies were also recruits so the highest taxonomic identification they could be assigned was family (Merulinidae).

Timed searches revealed an additional eight species had undergone bleaching than was found in the permanent plots. In addition to more $P$. versipora and $M$. mollis, we found bleached colonies of $P$. australensis, Turbinaria reniformis, Coelastrea aspera, Dipastrea favus, Turbinaria mesenterina, and Pocillopora damicornis (Table 2). The frequency of bleaching was significantly different between species (Chi-square test $p<0.05$ ) and the frequency of bleaching in the eight effected species was not independent of shelf position (inshore vs. offshore, Chisquare test $p<0.05$ ). This was likely the result of the large proportion of bleached $M$. mollis on offshore reefs and only bleached $M$. mollis and P. versipora being common to both inshore and offshore reefs (Table 2).

\section{DISCUSSION}

In this study we found corals in Marmion Marine Park $\left(32^{\circ} \mathrm{S}\right)$ to be largely unaffected by a severe marine cold spell. Our hypothesis, that corals would undergo bleaching and mortality was documented but not extensively. We had expected the unusually low temperature anomalies and duration of the MCS would have induced physiological stress, leading to a disruption in the coral-zooxanthellae symbiosis and to coral bleaching. However, this only occurred for a small number of corals and was not widespread across the coral community. The coastal area adjacent to Marmion Marine Park did not receive unusually high solar exposure between October-December 2016 compared to previous years (www.bom.gov.au) nor were other temperature anomalies seen in late 2016, ruling out warm water or light induced bleaching. This suggests that the symbiotic relationship

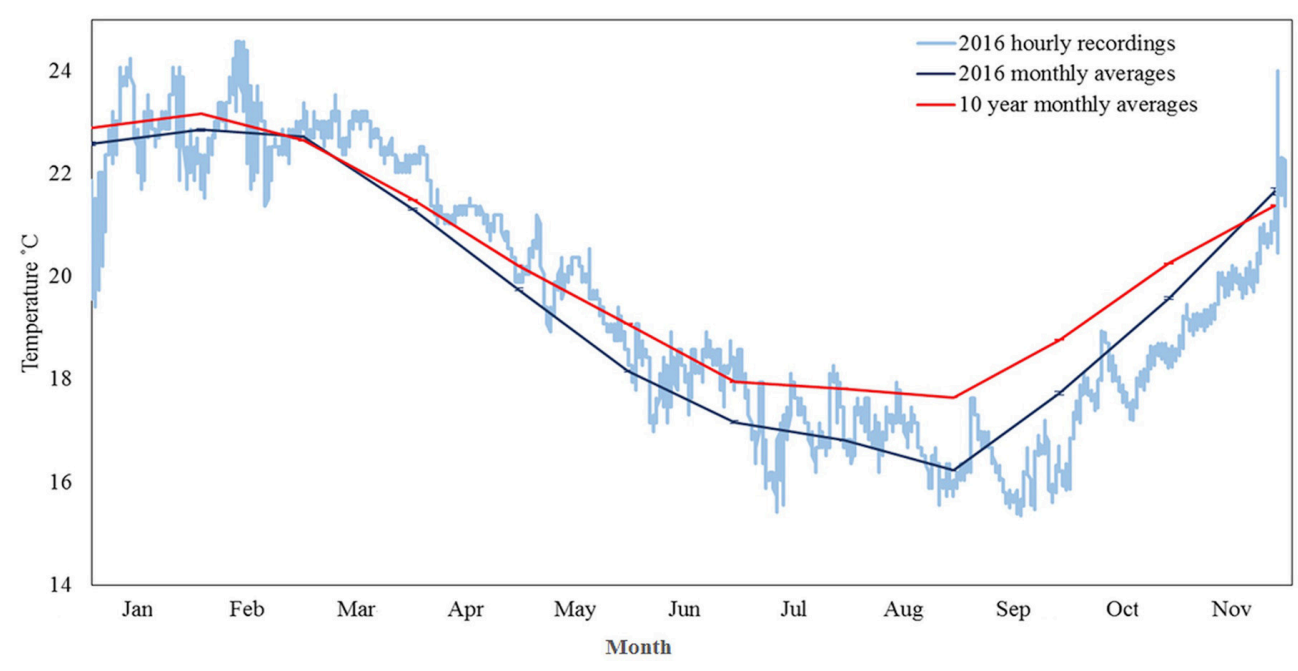

FIGURE 2 | In situ ( \pm se) temperatures logged by an Onset Tidbit logger attached to a stake $\sim 5 \mathrm{~cm}$ above the reef surface at Centaur Reef. Light blue line denotes hourly temperature records for 2016, dark blue line monthly temperature averages for 2016 and red line 10 year monthly (2006-2016) temperature averages. 


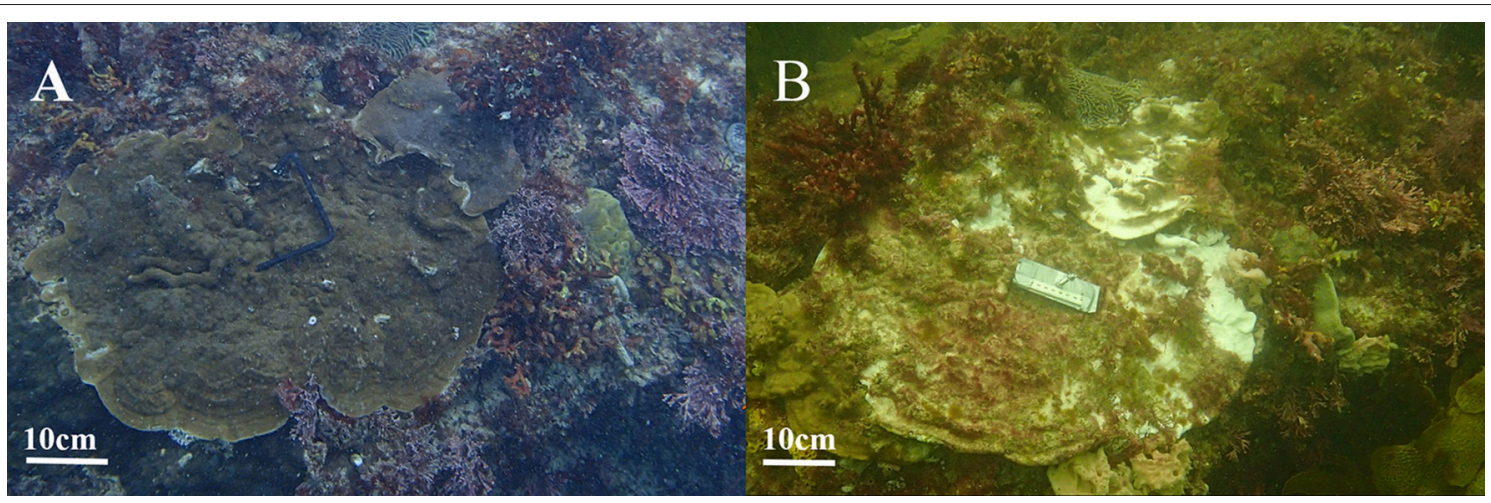

FIGURE 3 | Underwater photographs of coral colonies from Three Mile Reef South in Marmion Marine Park showing (A) healthy coral colonies in 2014 before the 2016 Marine Cold Spell and (B) bleached Montipora mollis colonies with turf algae overgrowth after, in January, 2017. Photo credits: C. Tuckett.

TABLE 1 | Relative abundances of species at different life stages before (2014) and after (2016) the Marine Cold Spell in permanent plots within Marmion Marine Park.

\begin{tabular}{llcc}
\hline Species & Life Stage & $\mathbf{2 0 1 4}$ & $\mathbf{2 0 1 6}$ \\
\hline Turbinaria reniformis & Adult & 2 & 2 \\
Montipora mollis & Adult & 5 & 5 \\
Favites abdita & Adult & 1 & 1 \\
Dipastrea favus & Adult & 2 & 2 \\
Coscinaraea mcneilli & Adult & 1 & 1 \\
Pocillopora damicornis & Adult & 1 & 1 \\
Turbinaria mesenterina & Adult & 1 & 1 \\
Plesiastrea versipora & Adult & 9 & 11 \\
Coelastrea aspera & Recruit & 19 & 24 \\
Paragoniastrea australensis & Adult & 7 & 11 \\
Total & Recruit & 0 & 3 \\
\hline Abult & Recruit & 8 & 21 \\
\hline
\end{tabular}

Abundances are from Three Mile Reef North and South only where plots where mapped for individual colonies, and recruits refer to colonies with a diameter $\leq 1 \mathrm{~cm}$.

between zooxanthellae and high latitude corals is not particularly stressed by anomalously cold temperatures, and that these corals are not persisting near their lethal temperature minima.

High latitude areas are challenging environments for inherently tropical taxa such as scleractinian corals. Low temperatures, low light availability and high attenuation in winter, low aragonite saturation and high competition with seaweeds are pervasive stressors for corals in these environments (Miller, 1995; Miller and Hay, 1996; Kleypas et al., 1999; Sommer et al., 2017). These stressors filter species so that high latitude coral communities are largely dominated by corals which are generalists with broad niche requirements (Sommer et al., 2014; Keith et al., 2015; Mizerek et al., 2016). The stress tolerant nature of most high latitude species could thus explain the low impact of the 2016 MCS.

It has been shown that low temperatures do not necessarily have detrimental impacts for corals and symbionts. Prolonged
TABLE 2 | Species found with coral bleaching after the Marine Cold Spell on inshore and offshore reefs of Marmion Marine Park, Perth, Western Australia in timed searches.

\begin{tabular}{|c|c|c|c|c|c|}
\hline \multirow[t]{2}{*}{ Species } & \multicolumn{2}{|r|}{ Offshore } & \multicolumn{2}{|r|}{ Inshore } & \multirow[b]{2}{*}{ Tota } \\
\hline & $N$ & Percent (\%) & $N$ & Percent (\%) & \\
\hline Montipora mollis & 17 & 42.5 & 6 & 15.0 & 23 \\
\hline Paragoniastrea australensis & 2 & 5.0 & 0 & 0.0 & 2 \\
\hline Plesiastrea versipora & 2 & 5.0 & 2 & 5.0 & 4 \\
\hline Turbinaria reniformis & 1 & 2.5 & 0 & 0.0 & 1 \\
\hline Coelastrea aspera & 0 & 0.0 & 2 & 5.0 & 2 \\
\hline Dipastrea favus & 0 & 0.0 & 1 & 2.5 & 1 \\
\hline Pocillopora damicornis & 0 & 0.0 & 3 & 7.5 & 3 \\
\hline Turbinaria mesenterina & 0 & 0.0 & 4 & 10.0 & 4 \\
\hline Total & 22 & 55.0 & 18 & 45.0 & 40 \\
\hline
\end{tabular}

$N=$ total count of bleached colonies per species, percent = percentage each species contributed to the total bleaching pool.

exposure to cold stress $\left(-5^{\circ} \mathrm{C}\right.$ below ambient) in aquaria has shown corals to acclimate and recover after initial declines in health and mild bleaching (Roth et al., 2012; Roth and Deheyn, 2013). One mechanisms enabling tolerance to cold stress, particularly when energy transfer from zooxanthellae to coral is absent or drastically reduced, is supplementing with heterotrophic feeding (Miller, 1995; Leletkin, 2000; Howe and Marshall, 2001; Anthony and Connolly, 2004; Grottoli et al., 2006; Houlbrèque and Ferrier-Pagès, 2009; Levas et al., 2013). Corals also maintain energy reserves (as lipids), which are utilized by some species to aid recovery after bleaching (Rodrigues and Grottoli, 2007). Thus mechanisms for energy acquisition may play an important role in managing stress to low temperatures such as those experienced during the 2016 MCS.

Although high latitude corals tolerate low temperatures these conditions often have sub lethal impacts. In broad terms, temperatures which regularly drop below $18^{\circ} \mathrm{C}$ for extended periods of time (weeks to months; Veron, 1995) are considered cold for corals as they limit reef building processes. In some areas of southern Australia, for example, temperatures can dip to $12^{\circ} \mathrm{C}$ (Petrusevics, 1993), however this is at the cost of 
A

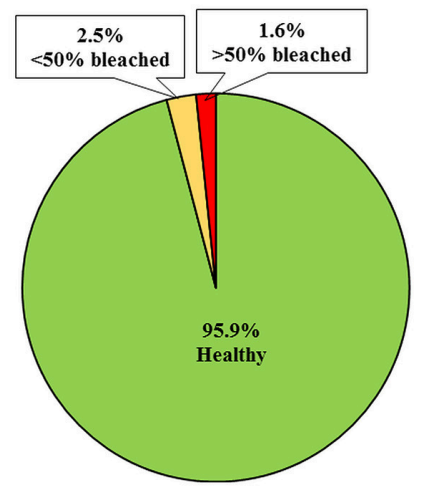

B

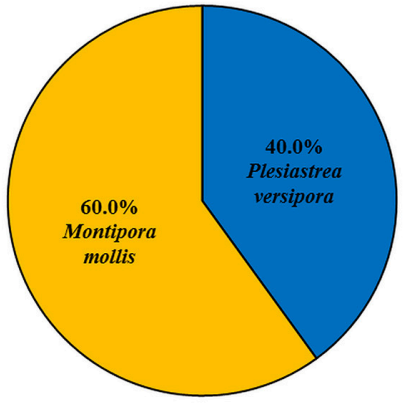

C

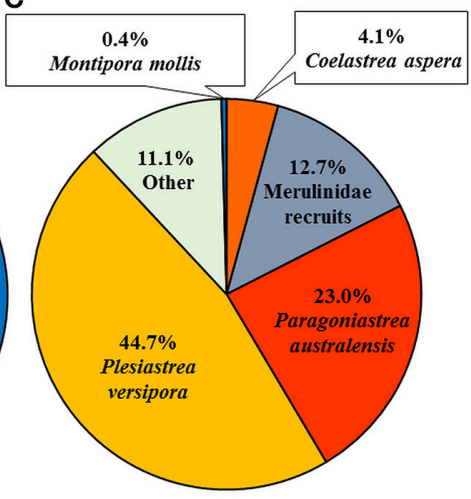

FIGURE 4 | Summary of coral colonies within long term growth plots in Marmion Marine Park as surveyed in January, 2017. (A) Proportion of coral colonies healthy, $<50 \%$ bleached and $>50 \%$ bleached, (B) species breakdown of the bleached corals, and (C) healthy corals.

growth which ranges from $1.5-7.8 \mathrm{~mm} \mathrm{year}^{-1}$ (Burgess et al., 2009). The 2016 MCS likely had similar sub lethal impacts and we expect that these corals would have depressed growth and possibly additional trade-offs such as reduced reproductive fitness.

It is clear that the 2016 MCS had little impact on high latitude corals in this study. This suggests that high latitude corals are not particularly limited by low temperatures, and other factors (potentially light, aragonite saturation and competition with seaweeds; Miller, 1995; Miller and Hay, 1996; Kleypas et al., 1999; Sommer et al., 2017) play a significant role. Therefore under a warmer future, temperature increase alone, may not make high latitudes any more suitable for coral performance than current conditions. However temperature increases have already indirectly alleviated competition with seaweeds at high latitude (Vergés et al., 2014; Tuckett et al., 2017), and its role in mitigating other limiting factors (e.g., light) has been proposed (Sommer et al., 2017). It has not been established if other environmental conditions are limiting these species, and if so,

\section{REFERENCES}

Anthony, K. R. N., and Connolly, S. R. (2004). Environmental limits to growth: physiological niche boundaries of corals along turbidity-light gradients. Oecologia 141, 373-384. doi: 10.1007/s00442-004-1647-7

Ayre, D. J., and Hughes, T. P. (2004). Climate change, genotypic diversity and gene flow in reef-building corals. Ecol. Lett. 7, 273-278. doi: 10.1111/j.1461-0248.2004.00585.x

Burgess, S. N., McCulloch, M. T., Mortimer, G. E., and Ward, T. M. (2009). Structure and growth rates of the high-latitude coral: Plesiastrea versipora. Coral Reefs 28, 1005-1015. doi: 10.1007/s00338-009-0533-5

Davis, G. E. (1982). A century of natural change in coral distribution at the Dry Tortugas: a comparison of reef maps from 1881 and 1976. Bull. Mar. Sci. 32, 608-623.

Firth, L. B., Knights, A. M., and Bell, S. S. (2011). Air temperature and winter mortality: implications for the persistence of the invasive mussel, Perna viridis in the intertidal zone of the south-eastern United States. J. Exp. Mar. Biol. Ecol. 400, 250-256. doi: 10.1016/j.jembe.2011.02.007

Gaines, S. D., and Denny, M. W. (1993). The largest, smallest, highest, lowest, longest, and shortest: extremes in ecology. Ecology 74, 1677-1692. doi: $10.2307 / 1939926$ what the implications are for coral performance on these reefs in a warmer future.

\section{AUTHOR CONTRIBUTIONS}

CT and TW designed the study; CT and TW collected data; CT identified corals, performed data analysis and led the writing; both authors contributed to the final version.

\section{FUNDING}

This study was funded by grants to TW from the Australian Research Council (DP170100023) and the Hermon Slade Foundation (HSF13/13).

\section{ACKNOWLEDGMENTS}

We thank E. Thomas, Y. Mulders, S. Straub, and M. Moustaka for assistance in the field.

Garrabou, J., Coma, R., Bensoussan, N., Bally, M., Chevaldonné, P., Cigliano, M., et al. (2009). Mass mortality in northwestern Mediterranean rocky benthic communities: effects of the 2003 heat wave. Glob. Chang. Biol. 15, 1090-1103. doi: 10.1111/j.1365-2486.2008.01823.x

Greenstein, B. J., and Pandolfi, J. M. (2008). Escaping the heat: range shifts of reef coral taxa in coastal Western Australia. Glob. Chang. Biol. 14, 513-528. doi: 10.1111/j.1365-2486.2007.01506.x

Grottoli, A. G., Rodrigues, L. J., and Palardy, J. E. (2006). Heterotrophic plasticity and resilience in bleached corals. Nature 440, 1186-1189. doi: 10.1038 /nature04565

Gunter, G. (1941). Death of fishes due to cold on the Texas coast, January, 1940. Ecology 22, 203-208. doi: 10.2307/1932218

Gunter, G. (1951). Destruction of fishes and other organisms on the south Texas coast by the cold wave of January 28-February 3, 1951. Ecology 32, 731-736. doi: $10.2307 / 1932740$

Hawkins, S. J., Sugden, H. E., Mieszkowska, N., Moore, P. J., Poloczanska, E., Leaper, R., et al. (2009). Consequences of climate-driven biodiversity changes for ecosystem functioning of North European rocky shores. Mar. Ecol. Prog. Ser. 396, 245-259. doi: 10.3354/meps08378

Hobday, A. J., Alexander, L. V., Perkins, S. E., Smale, D. A., Straub, S. C., Oliver, E. C. J., et al. (2016). A hierarchical approach to defining 
marine heatwaves. Prog. Oceanogr. 141, 227-238. doi: 10.1016/j.pocean.2015. 12.014

Hoegh-Guldberg, O., Fine, M., Skirving, W., Johnstone, R., Dove, S., and Strong, A. (2005). Coral bleaching following wintry weather. Limnol. Oceanogr. 50, 265-271. doi: 10.4319/lo.2005.50.1.0265

Holt, S. A., and Holt, G. J. (1983). Cold death of fishes at Port Aransas, Texas: January 1982. Southwest. Nat. 28, 464-466. doi: 10.2307/3670832

Houlbrèque, F., and Ferrier-Pagès, C. (2009). Heterotrophy in tropical scleractinian corals. Biol. Rev. Camb. Philos. Soc. 84, 1-17. doi: 10.1111/j.1469-185X.2008.00058.x

Howe, S. A., and Marshall, A. T. (2001). Thermal compensation of metabolism in the temperate coral, Plesiastrea versipora (Lamarck, 1816). J. Exp. Mar. Biol. Ecol. 259, 231-248. doi: 10.1016/S0022-0981(01)00230-1

Keith, S. A., Woolsey, E. S., Madin, J. S., Byrne, M., and Baird, A. H. (2015). Differential establishment potential of species predicts a shift in coral assemblage structure across a biogeographic barrier. Ecography 38, 1225-1234. doi: $10.1111 /$ ecog.01437

Kleypas, J. A., John, W. M., and Lambert, A. B. M. (1999). Environmental limits to coral reef development: where do we draw the line? Am. Zool. 39, 146-159. doi: 10.1093/icb/39.1.146

Krause, G. H. (1992). Effects of temperature on energy-dependent fluorescence quenching in chloroplasts. Photosynthetica 27, 249-252.

Leletkin, V. A. (2000). The energy budget of coral polyps. Russ. J. Mar. Biol. 26, 389-398. doi: 10.1023/A:1009497303413

Levas, S. J., Grottoli, A. G., Hughes, A., Osburn, C. L., and Matsui, Y. (2013). Physiological and biogeochemical traits of bleaching and recovery in the mounding species of coral Porites lobata: implications for resilience in mounding corals. PLoS ONE 8:e63267. doi: 10.1371/journal.pone.0063267

Lirman, D., Schopmeyer, S., Manzello, D., Gramer, L. J., Precht, W. F., MullerKarger, F., et al. (2011). Severe 2010 cold-water event caused unprecedented mortality to corals of the Florida reef tract and reversed previous survivorship patterns. PLoS ONE 6:e23047. doi: 10.1371/journal.pone.0023047

Miller, K. J., and Ayre, D. J. (2008). Protection of genetic diversity and maintenance of connectivity among reef corals within marine protected areas. Conserv. Biol. 22, 1245-1254. doi: 10.1111/j.1523-1739.2008.00985.x

Miller, M. W. (1995). Growth of a temperate coral: effects of temperature, light, depth, and heterotrophy. Mar. Ecol. Prog. Ser. 122, 217-225.

Miller, M. W., and Hay, M. E. (1996). Coral-seaweed-grazer-nutrient interactions on temperate reefs. Ecol. Monogr. 66, 323-344. doi: 10.2307/2963521

Mizerek, T. L., Baird, A. H., Beaumont, L. J., and Madin, J. S. (2016). Environmental tolerance governs the presence of reef corals at latitudes beyond reef growth. Glob. Ecol. Biogeogr. 25, 979-987. doi: 10.1111/geb.12459

Noreen, A. M. E., Harrison, P. L., and Van Oppen, M. J. H. (2009). Genetic diversity and connectivity in a brooding reef coral at the limit of its distribution. Proc. Biol. Sci. 276, 3927-3935 doi: 10.1098/rspb.2009.1050

Paz-García, D. A., Balart, E. F., and García-de-Léon, F. J. (2012). "Cold water bleaching of Pocillopora in the Gulf of California," in Proceedings of 12th International Coral Reef Symposium (Cairns, QLD) (Accessed July 9-13, 2012).

Petrusevics, P. M. (1993). SST fronts in inverse estuaries, South Australiaindicators of reduced gulf-shelf exchange. Mar. Freshwater Res. 44, 305-323. doi: 10.1071/MF9930305

Pontasch, S., Fisher, P. L., Krueger, T., Dove, S., Hoegh-Guldberg, O., Leggat, W., et al. (2017). Photoacclimatory and photoprotective responses to cold versus heat stress in high latitude reef corals. J. Phycol. 53, 308-321. doi: $10.1111 /$ jpy. 12492

Rehage, J. S., Blanchard, J. R., Boucek, R. E., Lorenz, J. J., and Robinson, M. (2016). Knocking back invasions: variable resistance and resilience to multiple cold spells in native vs. nonnative fishes. Ecosphere 7:e01268. doi: 10.1002/ecs2.1268

Roberts, H. H., Rouse, L. J. Jr., Walker, N. D., and Hudson, J. H. (1982). Coldwater stress in Florida Bay and northern Bahamas: a product of winter cold-air outbreaks. J. Sediment. Res. 52, 145-155.
Rodrigues, L. J., and Grottoli, A. G. (2007). Energy reserves and metabolism as indicators of coral recovery from bleaching. Limnol. Oceanogr. 52, 1874-1882. doi: 10.4319/lo.2007.52.5.1874

Roth, M. S., and Deheyn, D. D. (2013). Effects of cold stress and heat stress on coral fluorescence in reef-building corals. Sci. Rep. 3:1421. doi: 10.1038/srep01421

Roth, M. S., Goericke, R., and Deheyn, D. D. (2012). Cold induces acute stress but heat is ultimately more deleterious for the reef-building coral Acropora yongei. Sci. Rep. 2:240. doi: 10.1038/srep00240

Saxby, T., Dennison, W. C., and Hoegh-Guldberg, O. (2003). Photosynthetic responses of the coral Montipora digitata to cold temperature stress. Mar. Ecol. Prog. Ser. 248, 85-97. doi: 10.3354/meps 248085

Schlegel, R. W., Oliver, E. C. J., Wernberg, T., and Smit, A. J. (2017). Nearshore and offshore co-occurrence of marine heatwaves and cold-spells. Prog. Oceanogr. 151, 189-205. doi: 10.1016/j.pocean.2017.01.004

Smale, D. A., and Wernberg, T. (2009). Satellite-derived SST data as a proxy for water temperature in nearshore benthic ecology. Mar. Ecol. Prog. Ser. 387, 27-37. doi: 10.3354/meps08132

Sommer, B., Beger, M., Harrison, P. L., Babcock, R. C., and Pandolfi, J. M. (2017). Differential response to abiotic stress controls species distributions at biogeographic transition zones. Ecography 40, 001-012. doi: 10.1111/ecog.02986

Sommer, B., Harrison, P. L., Beger, M., and Pandolfi, J. M. (2014). Trait-mediated environmental filtering drives assembly at biogeographic transition zones. Ecology 95, 1000-1009. doi: 10.1890/13-1445.1

Southward, A. J., and Burrows, M. T. (1995). Seventy years' observations of changes in distribution and abundance of zooplankton and intertidal organisms in the western English Channel in relation to rising sea temperature. Plan. Perspect. 127, 155. doi: 10.1016/0306-4565(94)00043-I

Stehli, F. G., and Wells, J. W. (1971). Diversity and age patterns in hermatypic corals. Syst. Zool. 20, 115-126. doi: 10.2307/2412052

Thomas, L., Kennington, W. J., Evans, R. D., Kendrick, G. A., and Stat, M. (2017). Restricted gene flow and local adaptation highlight the vulnerability of highlatitude reefs to rapid environmental change. Glob. Chang. Biol. 23, 2197-2205. doi: $10.1111 /$ gcb.13639

Tuckett, C. A., de Bettignies, T., Fromont, J., and Wernberg, T. (2017). Expansion of corals on temperate reefs: direct and indirect effects of marine heatwaves. Coral Reefs, 36, 1-10. doi: 10.1007/s00338-017-1586-5

Vergés, A., Steinberg, P. D., Hay, M. E., Poore, A. G. B., Campbell, A. H., Ballesteros, E., et al. (2014). The tropicalization of temperate marine ecosystems: climate-mediated changes in herbivory and community phase shifts. Proc. Biol. Sci. 281, 20140846. doi: 10.1098/rspb.2014.0846

Veron, J. E. N. (1995). Corals in Space and Time: The Biogeography and Evolution of the Scleractinia. Cornell University Press.

Voss, G. L. (1973). Sickness and death in Florida's coral reefs. Nat. Hist. 82, 40-47. Wells, J. W. (1957). Coral reefs. Mere Geol. Soc. Am. 67, 609-631.

Wernberg, T., Bennett, S., Babcock, R. C., de Bettignies, T., Cure, K., Depczynski, M., et al. (2016). Climate-driven regime shift of a temperate marine ecosystem. Science 353, 169-172. doi: 10.1126/science.aad8745

Conflict of Interest Statement: The authors declare that the research was conducted in the absence of any commercial or financial relationships that could be construed as a potential conflict of interest.

The reviewer AWL and handling Editor declared their shared affiliation.

Copyright (c) 2018 Tuckett and Wernberg. This is an open-access article distributed under the terms of the Creative Commons Attribution License (CC BY). The use, distribution or reproduction in other forums is permitted, provided the original author(s) and the copyright owner are credited and that the original publication in this journal is cited, in accordance with accepted academic practice. No use, distribution or reproduction is permitted which does not comply with these terms. 